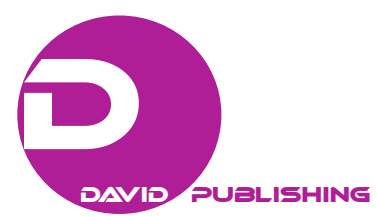

\title{
The Surname of Turkish Women: A Question of Identity?
}

\author{
Seldag Günes Peschke \\ Yildirim Beyazit University, Ankara, Turkey
}

\begin{abstract}
After the foundation of Turkish Republic in1923, Turkish Civil Code which was codificated from Switzerland in 1926 was a new code for modern Turkey that aimed gender equality. Even if, there were some articles, contrary to the equality of men and women, they were ignored when they were compared with the reforms performed in favor of women. The surname of woman was one of the issues where there was gender discrimination. In the Civil Code of 1926, it was stated that the married woman must have taken her husband's surname after the official marriage and she had to use it through her marriage life. In 1997, there was an amendment in TCC Article 153 that the married woman had the right to register her maiden name in front of her husband's surname which was also accepted in the new TCC in Article 187 in 2002. As the equality of the spouses is neglected under Article 187, many women are trying to change the current situation, by lawsuits. In this article, the regulations about the surname, will be discussed under personality rights and identity, within the current legislation with some court decisions from the last years in favor of women.
\end{abstract}

Keywords: surname, women, Turkish Civil Code, women rights, personality rights, identity, gender equality

\section{Introduction}

Social and political improvement, legal background are the most important factors for the development of women rights in Turkey. Towards the end of the 19th century, the status of women began to be improved to some extent. Turkish women played an important role, especially in the Turkey's War of Independence. Within the declaration of the Turkish Republic in 1923, the reforms of Atatürk gave Turkish women new rights and opportunities. By these reforms, a new secular legal system was introduced that completely affected women, marriage, and family relations.

\section{The Codification Movement After the Republic}

The reformation movement began with the modernization of the constitution, including the adaptation of European laws which were based on Roman Law ${ }^{1}$. The new legal system made all citizens equal before the law, the gender or the social status did not matter. By the codification of the Swiss Civil Code (ZGB) as Turkish

Seldag Günes Peschke, Ph.D., Professor, Head of Private Law, Faculty of Law, Yildirim Beyazit University.

1 Stein, 1999, p. 110; Sherman, 1917, p. 243; Williamson, 2008, p. 400; Schulz, 1946, p. 119; Roby, 2000, p. 75; Baumann, 1989, p. 39; Jolowicz \& Nicholas, 2008, p. 478; Towards the end of the 19th century, many European countries started to codify their laws according to the new social and political changes in Europe. First codifications were completed by Denmark (1687) and Sweden (1734). Later on, Prussia (1794), France (1804) and Austria (1811) adapted themselves to new legal systems. Later on, Prussia (1794), France (1804) and Austria (1811) adapted themselves to new legal systems. It could be recognised that French law and German law had common roots in Roman law. The French Civil Code was comprehensively accepted with some modifications in the Netherlands (1838), Italy (1865), Romania (1865), Portugal (1867), Spain (1888), Germany (1900), and Switzerland (1912). 
Civil Code (TCC) in 1926, women's situation before the law was improved according to the Ottoman times ${ }^{2}$.

The new Civil Code was a code of reforms for its age which abolished polygamy and recognized the equal rights of women in divorce, custody, and inheritance. It created a priviledge for women beyond its era. For that reason, some articles contrary to the equality of men and women didn't take so much attention at those times. TCC of 1926 brought many rules in favor of women, but it was taken into consideration vis-a-vis its own time.

During the 80 years, it became older because of the social and economic changes in Turkey. There was need to renovate some articles and make necessary arrangements. There were some unequal situations of women in some articles of the 1926 TCC and these were especially on family matters. There was an implicit gender discrimination in some articles of 1926 TCC. So, a comprehensive amendment was carried out to change various articles of the TCC since more than 50 years (GüneşPeschke, 2014, pp. 21-39).

\section{"Surname" in Turkish Civil Code}

Name is one of the most important personality rights that identifies an individual. It is inalienable, indispensable and connected closely to personality and identitiy ${ }^{3}$. The surname was one of the unequal legal situations in the TCC between man and woman. In the Civil Code of 1926 according to the Article 153, it was stated that the married women must have taken the surname of their husbands after the official marriage and they had to keep their husbands' name throughout their marriage life. In TCC, it was not mentioned that every citizen should have a surname. For that reason on 21 st June 1934, Surname Code was enacted which enforced every citizen to have a surname as a family name (Ünal Özkorkut, 2014, pp. 23-30, 23).

According to Surname Code Art. 1. "Every Turk should have a surname besides his/her first name". 4 Name has an important role on the personality. It is a sign to identify people in the society from the others. Even in the antiquity, it was used for the same aim to distinguish people from each other. Name has two parts for the real persons: first name and surname (Helvac1, 2012, p. 169; Akipek, Akıntürk, \& AteşKaraman, 2011, p. 419; Erdoğan, 1998, pp. 705-712, 705). First name determines people who are in the same family where surname passes from one generation to another. For that reason, surname shows the people to which family they belong to (Ataay, 1960, pp. 185-208, 187). The surname concerns and identifies a person in their private and family life regarding the ability to establish and develop social, cultural or other relationships with other people in the society ${ }^{5}$. Name is closely connected with the identity which is an integral part of identity. This includes also the digital identity by choosing nicknames. Nicknames are like masks. They protect the real identity, but create a cyber identity, as well (Peschke, 2015, pp. 117-126).

Under TCC and Surname Code, women had to take their husbands' name when they were married. So there was no alternative for them to reject to take the husbands' name. As 1926 TCC was a code of reforms for the time of its age, during more than 80 years, it became older because of the social and economic changes of the society. The women were much more aware of their rights according to the past. As a result, there was a need to change some articles and make necessary arrangements in the civil code, especially the unequal situations against women.

\footnotetext{
${ }^{2}$ Peirce, 2010, p. 368; Davis, 1986, p. 88; Ortayl1, 2010, p. 37; KabaklıÇimen, 2008, pp. 252-254; Ediz, 1995, p. 93; Lewis, 2009, p. 335; İnal, 2010, p. 533.

3 Y1lmaz, Ejder: Hukuk Sözlüğü (Law Dictionary), Ankara 2005, p. 26.

4 After Surname Code, Surname Regulations were in force on 27.12.1934 with similar arrangements.

5 mutatis mutandis, Niemietz, v. Germany, judgment of 16 December 1992, Series A no. 251-B, § 29.
} 
On 14 May 1997, there was an amendment in the Article 153 of the Civil Code that the married women had the right to register their maiden name in front of their husbands' surname. Afterwards, on 22 November 2001 the new Civil Code was enacted and the new TCC was valid after 1st January 2002. The aim of the reforms of 2002 TCC was to place married women on an equal position with their husband in representing the couple, in economic activities and in the decisions to be taken affecting the family and children. With the new TCC, the husband's role as head of the family has been abolished. Both married couple have acquired the power to represent the family (Akıntürk, 2008). Although there were positive changes in the TCC in favor of women, the provisions concerning the family name after marriage, including those obliging married women to take their husbands' name, have remained unchanged.

In the new civil code, the surname was regulated under article 187, instead of 153 of the old TCC, which kept the same regulations, according to the change in 1997. It is stated in the Article 187 of 2002 TCC that, the married woman must take the surname of her husband's, after the official marriage. Besides, she had the right to register her maiden name in front of her husband's surname. Now the current situation is the same as 1997 and 2002, that the wife can use her maiden name (surname from her family) only together with her husband's surname $^{6}$. In another sense, women can have the possibility to keep their maiden names after the marriage, but they are obliged to use their maiden names only with their husbands' surname. So, according to TCC, married women in Turkey cannot use their maiden names alone without their husbands' surname, even if both spouses make an agreement for that. There has been a big debate in the last years over the surname of the married woman.

\section{"Name" as a Part of Personality Rights: In International Treaties and Current Turkish Regulations}

After marriage the woman is forced by law to use another surname than her maiden name ${ }^{7}$. Name is considered as one of the personality rights. The name of a person is a part of personality rights. A person's name is important not only in the construction of his/her identity, but also it is a part of his/her identity which he/she keeps in all through his/her life.

Personality rights are mentioned in several international treaties. According to the Universal Declaration of Human Rights (UDHR) dated 10 December 1948, Article 12, "No one shall be subjected to arbitrary interference of his privacy, family, home or correspondence, nor to attacks upon his honour and reputation. Everyone has the right to the protection of the law against such interference or attacks".

In the European Convention on Human Rights (04 November 1950), in article 8, it is stated that everyone has the right to respect for his private and family life, his home and his correspondence ${ }^{8}$. This article respects private life and protects people against interference by other individuals.

\footnotetext{
${ }^{6}$ In this subject there is a European Court of Human Rights decision (UnalTekeli-Turkey case) which indicates that woman can use her own name without the surname of her husband, but the amendments for this change have not been made in the Civil Code. So this decision is enforceable only for this case. As it doesn't create a general rule, TCC Art. 187 is applied to all the cases about the surname of the married woman which means that women can use their maiden names only with their husbands' surname (http://turkey.setimes.com/en_GB/articles/ses/articles/features/departments/national/2013/09/17/feature-01, 17.09.2014).

7 Zevkliler/Havutçu, p. 132.

${ }^{8}$ In the European Convention on Human Rights article 2/2 states that there shall be no interference by a public authority with the exercise of this right. There can be exceptions in accordance with the law and when it is necessary in a democratic society in the interests of national security, public safety, the economic well-being of the country. The prevention of disorder or crime, the protection of health or morals, and the protection of the rights and freedoms of others are also included in these exceptions.
} 
Article 8 of the Convention does not contain any specific provisions on names, but as a means of personal identification and the link to the family, a person's name concerns definetely, his or her private and family life ${ }^{9}$.

According to the Article 14 of the convention "The enjoyment of the rights and freedoms set forth in [the] Convention shall be secured without discrimination on any ground such as sex, race, colour, language, religion, political or other opinion, national or social origin, association with a national minority, property, birth or other status".

Besides these basic treaties there is an other convention which is inforce in the last years. Convention on the Elimination of All Forms of Discrimination against Women (CEDAW), strongly supports protection of women and girls through law and provides concrete strategic guidance for actions to be taken for the equality of women and men under legal regulations ${ }^{10}$. According to Turkish Constitution Article 90, "International agreements duly put into effect have the force of law. In the case of a conflict between international agreements, duly put into effect, concerning fundamental rights and freedoms and the laws due to differences in provisions on the same matter, the provisions of international agreements shall prevail".

In the Turkish Constitution the privacy of individual life (Arasl1, 1979) and the nature of fundamental rights and freedoms are published in two different articles (Article 12 and 20) ${ }^{11}$. Everyone possesses inherent fundamental rights and freedoms which are inviolable and inalienable. The fundamental rights and freedoms also comprise the duties and responsibilities of the individual to society, their family, and other individuals. The privacy of individual life is also taken under protection as everyone has the right to demand respect for his private and family life. It is added that the privacy of an individual or family life cannot be violated (GüneşPeschke, 2014, pp. 21-39; Bayraktar, 2007, p. 111). Besides, in Article 17 it was regulated that everyone has the right to life and the right to protect and improve his/her corporeal and spiritual existence.

The fundamental rights are protected under Turkish Constitution while the personality rights in TCC (Moroğlu, 2004, pp. 281-307, p. 282). The personality rights are not specified individually in this code, as numerous clausus principle is not accepted. The legislator did not want to limit the content of the personality rights. For that reason, all the values that are related with the personality can be included in the personality rights $^{12}$ like name, life, honour, freedom, health, body, secrets, photos, voice, and many more (Dural \& Öğ̈̈, 2006, p. 98; Özsunay, 1982, p. 98; Akipek, Akıntürk, \& AteşKaraman, 2011, p. 56). But especially, some of them are protected in different articles separately because of the importance given to the subject, for example name is one of these, which is protected against infregements in TCC Article 26-27, besides the general rules about personality in articles 23,24 , and 25 . TCC Art. 24 protects the personality against the individuals who made the assault. The breach against personal rights is considered contrary to the law unless the assent of the person whose personality right is damaged, is based on the reasons related to private or public interest and use of authorisation conferred upon by the law.

\footnotetext{
9 Ünal-Tekeli v TurkeyJudgement, p. 11.

10 Ünal Özkorkut, p. 27.

11 The right to legal protection of private life, honour, name and the right to determine one's private life were introduced in Turkish Constitution which also contains guarantees of freedom to communicate and protection of secrecy of communication, guarantees of freedom to express opinions and to obtain and disseminate information, as well as guarantees of consumer protection against the actions threatening their privacy.

12 Honsell, H./Vogt, N.P./Geiser, T.: Basler Kommentar, Zivilgesetzbuch I, 3. Auflage, 2006, Basel-Genf-München, Art. 28, N.8; 4. H.D. 10.02.1998, 9037/317 (YKD. 1998/4, s. 509).
} 


\section{The Infregment of Personality Rights for Women in the Usage of "Surname" After Marriage}

Changing the name of a person with the legal regulations, without her will, as mandatory can be determined as an infringement against her personality rights, and this leads to a confusion in the society. A person's name was particularly important in the construction of his/her identity. To change woman's maiden name as a result of her marriage can rise to an irreversible severance with her past. Besides, it can be thought that, Article 187 is against the Constitution Article 10, which states that legally men and women have equal rights. In another sense, TCC accepts that men can use their surnames all through their lives, where this right is not given to women ${ }^{13}$.

Ünal/Tekeli case is one of the first which took the subject to European Court of Human Rights (Council of Europe). A woman who is practicing her legal training opened a suit that she can not use her own surname alone after her marriage whereas Turkish law allowed married men to bear their own surname all through their lives. She submitted that this resulted in discrimination on grounds of sex and was incompatible with Article 8 taken together with Article 14 of the European Convention on Human Rights (there was a breach of Article 8, in accordance with the Article 14). According to ECHR, the applicant's complaint concerns the fact that, legally, married women cannot use their maiden name alone after they marry whereas married men keep the surname they had before, when they were married. This is undoubtedly a "difference in treatment" on grounds of sex between persons in an analogous situation. The Court stated that there was discrimination in the current regulations on "Surname" between man and woman in $\mathrm{TCC}^{14}$. As a result the Court decided in favor of the plaintiff and against the Turkish regulations.

The Constitutional Court decided in 2011 on a similar case, about the surname of a woman that there is no discrimination and breach of constitution, in the change of woman's surname after marriage ${ }^{15}$. Under the case, it was requested that the Article 187 should have been cancelled, as this article was against several articles (2., 10., 12., 17., and 41. ) of the Constitution ${ }^{16}$.

In the Turkish Constitution Article 10, it is stated that everyone is equal before the law without distinction as to language, race, colour, sex, political opinion, philosophical belief, religion and sect, or any such grounds. Men and women have equal rights. The State has the obligation to ensure that this equality exists in practice. It is also stated in Article 41 that family is the foundation of the Turkish society and based on the equality between the spouses. This equality should be considered before law and also in social life in every situation.

According to Turkish Constitutional Court, Article 10 of the Constitution, under the context of surname, there is no any discrimination on the ground of sex. Because, "the principle of equality within the meaning of

\footnotetext{
13 There is an article (Article 173) for divorced women, which states that a woman is allowed to retain her former husband's name only if he agrees on it or if she proves, that she has an interest in using this name. The judge can give a decision in favor of the woman to use her ex-husband's surname. But in the future, if the conditions change and the husband does not want, he has the right to take his surname back from the woman.

${ }_{14} \mathrm{http} / / /$ www.menschenrechte.ac.at/orig/04_6/Unal\%20Tekeli.pdf (29.09.2015), p. 11.

15 The decision of the Constitutional Court dated 10.03.2011, No. 2009/85 E., 2011/49 K.

16 In Turkish Constitution Article 2-The Republic of Turkey is a democratic, secular and social state governed by rule of law, within the notions of public peace, national solidarity and justice, respecting human rights, loyal to the nationalism of Atatürk, and based on the fundamental tenets set forth in the preamble. Article 12-Everyone possesses inherent fundamental rights and freedoms, which are inviolable and inalienable. Article 17-Everyone has the right to life and the right to protect and improve his/her corporeal and spiritual existence. Article 41 - Family is the foundation of the Turkish society and based on the equality between the spouses.
} 
Article 10 of the Constitution does not mean that everyone is subject to the same rules of law". The special characteristics of each person or each group of persons may reasonably justify the application of different rules of law. The rule according to which married women use their husband's name derives from certain social realities and is the result of the codification of certain customs that have formed over centuries in Turkish society ${ }^{17}$. Constitutional Court comments that the purpose of the rule Art. 187 is to establish the family unity and protect women, who are in a more delicate nature than men ${ }^{18}$. This decision is strongly discussed in the doctrine, among women's associations and politicians.

In the Article 20 of the Constitution, it is regulated that everyone has the right to demand respect for his/her private and family life. Privacy of private or family life shall not be violated. Besides the Article 41 states that family is the foundation of the Turkish society and based on the equality between the spouses. Under this concept, of course "customs and local traditions" are important, but it should be clear that these legal systems should not include any discriminatory provisions. According to European Union regulations, although it is difficult, while making a norm in any subject, the diversity of customs and local traditions should be respected and it should be seen possible to form a uniform system.

In this case in 2011, the Constitutional Court refused to cancel Article 187. According to Article 152/4, no claim of unconstitutionality shall be made with regard to the same legal provision until 10 years elapse after publication in the Official Gazette of the decision of the Constitutional Court dismissing the application on its merits which means that, the cancellation of the same article can not be asked again within the 10 years.

\section{The Legal Implementations in the Last Years in Favour of Women's Surname}

Under all these contradictions about the surname of women between the legal regulations in Turkey and the international treaties, the subject was taken to the Constitutional Court in several times. In the Constitutional Court decisions, it was generally stated that there was a link between family unity and the family name which the married woman had to take after the marriage. It was thought that because of the Turkish traditions, the family unity was reflected in a joint name which is considered as the husband's name.

SevimAkatEşki was a lawyer from Istanbul who was using her maiden name with her husband's surname. She took the subject to the court, just to use only her maiden name during her marriage in 2013. In the jurisdiction procedure, both the local court and the Supreme Court of Appeals rejected her demand. So, she made an individual application to the Constitutional Court to use only her maiden surname without her husband's surname ${ }^{19}$. The Constitutional Court found her claims right and decided in favor of her. The lawsuit was sent to the 1 . Instance Court again to give the last decision, as in the Turkish jurisdiction system, the Constitutional Court decisions are binding for the courts in the same subject matter.

Two years after this decision, another lawyer, NeşeAslanbayAkbıyık opened a lawsuit to use only her maiden name, without her husband's surname. Then, both the local court and the Supreme Court of Appeals rejected her demand. At the end, she made an individual application to the Constitutional Court to use only her maiden surname without her husband's surname ${ }^{20}$.

\footnotetext{
${ }^{17}$ http://www.resmigazete.gov.tr/eskiler/2011/10/20111021-8.htm.

${ }^{18} \mathrm{http}: / /$ www.kararlaryeni.anayasa.gov.tr/Karar/Content/8d95104c-3cad-4461-bae2-a1b1a3b59dc8?excludeGerekce=True\&words Only=False.

19 http://www.kararlaryeni.anayasa.gov.tr/BireyselKarar/Content/68aa4186-521f-4bf9-9c03-f0e0bbf55a88?wordsOnly=False.

${ }^{20} \mathrm{http}: / / w w w . k a r a r l a r y e n i . a n a y a s a . g o v . t r / B i r e y s e l K a r a r / C o n t e n t / 68 a a 4186-521 \mathrm{f}-4 \mathrm{bf} 9-9 \mathrm{c} 03-\mathrm{f0e} 0 \mathrm{bbf55a88}$ ?wordsOnly=False(29.0 9.2015).
} 
The Constitutional Court gave a decision in 16 April 2015, similar to SevimAkatEşki case, that preventing woman from using her maiden name after marriage, is a violation of Article 17 on the personal inviolability and corporeal and psychological existence of the individual. The Constitutional Court decided that plaintiff's rights regarding Article 17 had been violated. Name is one of the most important personality rights that identifies an individual. It is inalienable, indispensable and connected closely to personality and identity. Preventing women from using only their maiden name after marriage is against equality between the couples and article 17 of the Constitution. In Article 17 it was regulated that everyone has the right to life, the right to protect and improve his/her corporeal and spiritual existence. As a result, the constitutional court decided which is contrary to its earlier decisions, that any married woman can use only her maiden surname after marriage by the decision of the court.

The Constitutional Court has ruled in 2015 that preventing woman from using her maiden name after marriage is a violation of Article 17 on the personal inviolability and corporeal and psychological existence of the individual. The Constitutional Court decided that AslanbayAkbiylk's rights regarding Article 17 had been violated, as the same as AkatEşki's.

The last decision from the Court of Cassation Assembly of Civil Chambers was a turning point for the married women's surname. On 30 September 2015 there was a decision from the Court of Cassation Assembly of Civil Chambers that the woman could use only her maiden name after marriage without her husband's surname. In the Assembly of Civil Chambers it was voted 45 to 2 in favor of the woman's surname that married woman can use only her maiden surname without her husband's surname. This decision is important because, it is the latest decision from one of the highest judicial jurisprudence given in favour of women, opposite to the old ones.

As a result, the last court decisions show that there is a big change in the opinions of the Constitutional Court and The Court of Cassation that the woman can use only her maiden surname, while she is keeping her family unity.

According to Turkish legislation, the decision of the Constitutional Court is not applied to all women. For that reason, to spread this court decision to the wide in general to all married woman, Article 187 should be changed in a way that the woman should have the possibility to use only her maiden name after marriage, without husband's surname.

\section{References}

Akıntürk, T. (2008). TürkMedeniHukukuAileHukuku (Turkish Civil Law Family Law). İstanbul: Beta.

Akipek, J., Akıntürk, T., \& AteşKaraman, D. (2011). TürkMedeniKanunuBaşlangıçHükümleriKişiler Hukuku (Turkish Civil Law, Law of Persons). İstanbul: Beta

Araslı, O. (1979). Özel Yaşamın Gizliliği Hakkı ve T.C. Anayasası'nda Düzenlenişi (Privacy in Turkish Constitution) (Unpublished).

Ataay, A. (1960). Medeni Hukukta Adla İlgili Temel Bilgiler (Main Information about Name in Civil Code). Istanbul Üniversitesi Hukuk Fakültesi Mecmuası (Istanbul University Law Review), 26(1-4), 185-208.

Ayan, M., \& Ayan, N. (2011). KişilerHukuku (Law of Persons). Konya: Mimoza.

Baumann, R. (1989). Lawyers and politics in the Early Roman Empire. München: Beck.

Bayraktar, K. (2007). Özel Yaşamın Gizliliğine Saygı İlkesi (The respect on privacy). Maltepe University Law Journal, 1, 119-129.

Davis, F. (1986). The Ottoman Lady A Social History From 1718 to 1918. Westport, Conn.: Greenwood Press.

Dural, M., \& Öğüz, T. (2006). TürkÖZelHukuku (Turkish Private Law). İstanbul: Filiz.

Ediz, Z. (1995). Introduction to women's history. İstanbul: AdımYayınları. 
Erdoğan, İ. (1998). Şahsiyeti İncitici Soyadı Meselesi (The problem of surname which hurts the personality). Selçuk Üniversitesi Hukuk Fakültesi Dergisi (Selçuk University Law Review), 6(1-2), 705-712.

GüneşPeschke, S. (2014). The legal status of Turkish women: Past and present under the Turkish civil code. Ankara Bar Review, 7(1), 21-39

Helvac1, S. (2012). Gerçek Kişiler (Real Persons). İstanbul: Legal.

Honsell, H., Vogt, N. P., \& Geiser, T. (2006). Basler Kommentar, Zivilgesetzbuch (The Commentary of Basler, Civil Code) I, 3. Auflage, 2006, Basel-Genf-München.

İnal, H. İ. (2010). OsmanlıTarihi (Ottoman history). İstanbul: NoktaKitap.

Jolowicz, H. F., \& Nicholas, B. (2008). Historical introduction to the study of Roman law (3th ed.). Cambridge: Cambridge University Press.

KabaklıÇimen, L. (2008). TürkTöresinde Kadın veAile (Women and family in Turkish customs). İstanbul: IQ Kültür.

Lewis, B. (2009). Modern Türkiye'ninDoğuşu (The rise of modern Turkey) (Çeviren: BoğaçBabürTurna) (3th ed.). Ankara: TürkTarihKurumu.

Moroğlu, N. (2004). Kadının Soyadı (The Surname of woman). İstanbul: Vedat Kitapçılık.

Ortaylı, İ. (2010). Osmanlı'yı YenidenKeşfetmek-1 (Rediscovering Ottoman). İstanbul: TimaşYayınları.

Özsunay, E. (1982). GerçekKişilerinHukukiDurumu (The legal situation of real persons) (5th ed.). İstanbul: Der Yayınları.

Öztan, B. (1979). AileHukuku (Family Law). Ankara: Turhan.

Peirce, L. P. (2010). Harem-iHümayun, OsmanlıImparatorluğu'ndaHükümranlıveKadınlar (Harem, women and sovereignty in the Ottoman Empire) (5th ed.). İstanbul: TarihVakfi Yurt Yayınları.

Peschke, L. (2015). The Web never forgets!: Aspects of the right to be forgotten. Gazi University Faculty of Law Review, 19(1), $117-126$.

Roby, H. J. (2000). An introduction to the study of Iustinianus Digest. Union/New Jersey: Book On Demand Ltd.

Schulz, F. (1946). History of Roman legal science. Oxford: Clarendon Press.

Sherman, P. C. (1917). Roman law in the modern world (vol. I). Boston: Boston, U.S.A.: Boston Book Co.

Stein, P. (1999). Roman law in European history. Cambridge: Cambridge University Press.

Ünal Özkorkut, N. (2014). Kadının Vazgeçilebilir Kişilik Hakkı: soyadı-Kadının Soyadı Üzerindeki Hakkının Türkiye'deki Tarihsel Gelişimi (The dispensable personality right of woman: Surname-The history of woman's surname in Turkey). Proceedings from I. Türk Hukuk Tarihi Kongreleri (1. Legal History Congress) (pp. 23-30), İstanbul.

Williamson, C. (2008). The laws of the Roman people. Michigan: University of Michigan Press.

Zevkliler, A. (1992). MedeniHukuk (Civil Law) (3th ed.). Ankara: SavaşYayınları.

Zevkliler, A., Havutçu, A., Gürpınar, D., \& Ertaş, Ş. (2013). MedeniHukukTemelBilgiler (Civil law the main principles) (8th ed.). Ankara: TurhanKitabevi. 